\title{
Biological Attributes of Diaphorina citri Kuwamaya on Citrus limetta under Controlled Conditions
}

\author{
Archi Roy ${ }^{1}$, Parvez Qamar Rizvi ${ }^{2}$ and Neha Sinha $^{3}$
}

${ }^{1}$ Department of Plant Protection, ${ }^{2}$ Department of Plant Protection, Faculty of Agricultural Sciences, Aligarh Muslim University, Aligarh-202002, Uttar Pradesh, India

${ }^{3}$ Department of Fruit and Fruit Technology, Bihar Agricultural University, Sabour Bhagalpur-813210, Bihar, India

*Corresponding author

\section{A B S T R A C T}

Keywords

Psyllids, Huanlongbing, diapause and instars

Article Info

Accepted: 05 February 2020 Available Online: 10 March 2020
The present experiment was commenced under the laboratory condition to studythe biological parameters of Diaphorina citri Kuwayama. The psyllid species, Diaphorina citri is potentially the most dangerous at the present time because it serves as vector for Citrus Huanlongbing which is the most serious disease of citrus in the world. Diaphorina citriis the only known vector of Huanglong-bing- a phloem-limited bacterial disease of international importance. Adults and nymphs suck sap from the phloem of tender shoots and buds, whilst adults also feed on the phloem of mature leaves. Severe infestations in orchards could lead to withering, distortion, and loss of immature leaves and irregularshaped canopies. Citrus psylla are prevalent throughout the year but the high population coincides with the periods of new vegetative flushes on citrus plants during spring and summer. The population is sensitive to high rainfall and moisture condition and survives throughout the year without diapause, completing about 9-10 generations per year. The life cycle of Asian Citrus Psylla includes an egg stage and five nymphal instars. Study of citrus psyllid biology is necessary for decision making of appropriate management strategies and to reduce the economic damage.

\section{Introduction}

Citrus spp. is susceptible to a number of destructive diseases and insects that are continuously emerging and which can severely limit production or totally decimate an industry of a country. The psyllid species, Diaphorina citri is considered as potentially the most dangerous at this time because it serves as vector for Citrus Huanlongbing. Citrus greening disease or Huanglongbing is the most serious disease of citrus in the 
world (Aubert et al., 1996). The Asian Citrus Psylla, Diaphorina citri Kuwayama is worth noting as vector of an endocellular, phloemrestricted bacterium, associated with the Citrus greening disease (CGD). CGD is a destructive malady seriously affecting most commercially important Citrus cultivars in Africa and Asia. Yield reductions of 23\% from 2006 to 2011, revenue losses of $\$ 1.71$ billion and the losses of 8,257 jobs directly or indirectly related to this industry was estimated. NASS statistics show orange production in Florida decreased from 6.94 to 3.33 billion tones $(67.4 \%$ reduction) over the 8-year interval from 200708 to 2015-16 seasons (NASS, United States Department of Agriculture, 2015-16).Six other species of Diaphorina are reported on citrus, but these are non-vector species of relatively little importance (Halbert and Manjunath 2004). About 823 species have been reported attacking on Citrus, among them 175 have been found in India (Ebeling, 1959), whereas 34 species are actively recorded from Punjab and Uttar Pradesh (Devi et al., 2014).In which asiatic citrus psyllid (Diaphorina citri Kuwayama [Hemiptera: Psyllidae] was recognised as a major pest of citrus in subtropical and tropical Asia, initially in India and then elsewhere in the region (Halbert and Manjunath, 2004.) Itisthemost efficient vector of citrus greening bacterium (Candidatus Liberobacter asiaticum) throughout Asia and the Far East (Catling, 1970). Due to their jumping and feeding habits its status derives, not from the damage it causes, but from its role as the only known vector of Huanglongbing- a phloem-limited bacterial disease of international importance. Adults and nymphs suck sap from the phloem of tender shoots and buds, whilst adults also feed on the phloem of mature leaves. Severe infestations in orchards could lead to withering, distortion, and loss of immature leaves and irregular-shaped canopies. Growth of sooty mould fungi on honeydew excreted by nymphs leads to blemishing of foliage and fruit, and can reduce photosynthesis (Wang et al.; 2002). The disease can devastate orchards within a few years of planting. It also poses a major threat to endangered indigenous citrus germplasm in Asia. The population is sensitive to high rainfall and moisture condition and survives throughout the year without diapause, completing about 9-10 generations per year (Husain and Nath, 1927). Despite of its wide occurrence and serious damage to citrus crop, very little attention has been given to this pest especially in generating the pin point information on development and reproductive potential of citrus psylla, D.citri. Therefore, the present investigation has been aimed to study the biology of D.citri, as management strategies of an insect pest must be based on thorough ecological studies of the concerned insect pest.

\section{Materials and Methods}

The present work and experiment commenced in February 2019 under the laboratory condition at Department of Plant Protection, Faculty of Agricultural Sciences, Aligarh Muslim University, Aligarh, Uttar Pradesh, India. The biological parameters of Diaphorina citri Kuwayama, were studied on Citrus limetta at a temperature range of $25-27^{\circ} \mathrm{C}$ and $60-70 \%$ relative humidity in a BOD incubator. The adults of D.citri were collected from a mature, fruiting tree of Citrus limetta by an aspirator (Plate 4-K) and brought to laboratory conditions to maintain the stock culture (Plate 3-J). The adult females were singly aspirated into big glass jars and was covered by muslin cloth on top. Tender twigs wrapped with moist cotton and placed in the water plastic container, 2 X $5 \mathrm{~cm}$ (diameter X depth) served as a food source. Two males were also released into it. The jars were checked constantly for egg laying.For incubation study, shoots along with freshly laid eggs were cut and transferred in petri dishes after one day of adult release. Cut ends of detached shoots 
were dipped in water and wrapped with moist cotton and placed in petri dishes. For nymphal period study, nymph immediately after hatching, were picked up with soft moist camel hairbrush and transferred to a fresh tender twig singly and placed in petri dish and cut ends were kept moist by wrapping moist cotton wool. Tender twigs were provided as food material and transferred twice, daily during the early instar and once during later instars. The hatching period, nymphal duration, oviposition period and adult longevity were recorded daily. Adults were also kept in clip cages made in laboratory to study the fecundity (Plate 4-L). Five such cases were hanged on a single tree.

\section{Results and Discussion}

It was found that psyllid's life cycle included an egg stage and five nymphal instars(Plate 1). Eggs were oviposited in clusters on leaf folds, petioles, axillary buds, upper and lower surfaces of young leaves and tender stems (Plate 1). Pre-oviposition period lasted for $1.4 \pm 0.55$ days (Table 1). The egg laying started on fourth day with an incubation period of $1.4 \pm 0.55$ days and oviposition lasted for 18.22 \pm 1.30 days (Table 1). Eggs were anchored on a stalk-like process arising from the plant tissue. They were somewhat conical, almond shaped with a broad basal end and tapering towards its distal end (Plate 1-A). Light yellow coloured eggs deposited freshly, turned bright orange later with two distinct red eye spots at maturity. Egg shell turned transparent and membranous after hatching and remain attached to the plant tissue (Plate 1-B). All the nymphs reared underwent four moults, continuously secreted a copious amount of honeydew from anus and a thread like waxy substances from the circumanal glands resulting in the growth of black sooty mould on the lower leaves. The early instars were docile and moved slightly on disturbances while older nymphs and adults were highly mobile and jump frequently. They feed on tender and succulent leaves (Plate 2-I). Newly emerged nymphs were pale yellow in colour and developed wings can be clearly seen in the last instar (Plate 1-F). The duration for first, second, third, fourth and fifth instar were recorded as $3.20 \pm 0.84,2.80 \pm 0.84$, $3.60 \pm 0.89,3.80 \pm 0.84,4.20 \pm 0.84$ days (Table $1)$. Fecundity of an adult female was recorded to be 321.2 \pm 52.51 eggs (Table 1). Adult longevity was recorded $27.40 \pm 1.67$ days for female and $22.60 \pm 2.88$ for male psylla (Table 1). Adults are adapted for sucking plant vessels, by the means of elongated mouth parts. The metathoracic legs are highly modified for jumping and the forewings remain folded in roof-like fashion (Plate 2-G and $\mathrm{H}$ ). Life cycle of male and female were completed in $40.20 \pm 2.86$ and $45.00 \pm 2.53$ days respectively (Table 1).Husain and Nath, 1927 observed that nymphs are yellow in colour, flattened and circular in shape, remain congregated close to the site of oviposition for feeding and move to matured leaves, thick shoots and petioles. As described by Hall and Albrigo (2007), oviposition and development of immature D. citri are confined to young, tender flush leaves.Tsai and Liu, 2000 reported that the egg is anchored to plant tissue on a slender stock-like process on one end in an upright position, and large numbers of eggs may be found on a single flush shoot. Chhetry et al., 2012 reported that nymphs move slowly in early stage and body size increases at a very slow pace. Chhetry et al., 2012 also reported similar findings regarding nymphal periods. He observed the developmental range of $3.42 \pm 0.17$ days, $2.17 \pm 0.21$ days, $2.52 \pm 0.18$ days and $3.07 \pm 0.31$ days for first, second, third, fourth and fifth instars respectively. According to Richardson and Hall; 2013, female survives longer than the male. My findings revealed the same. Khan et al., 1989 and Xu et al., 1994 stated that D.citri completes 6-7 generations per year or even upto 16 generations in a single year. 
Table.1 Duration of different development stages of Diaphorina citrion citrus plant

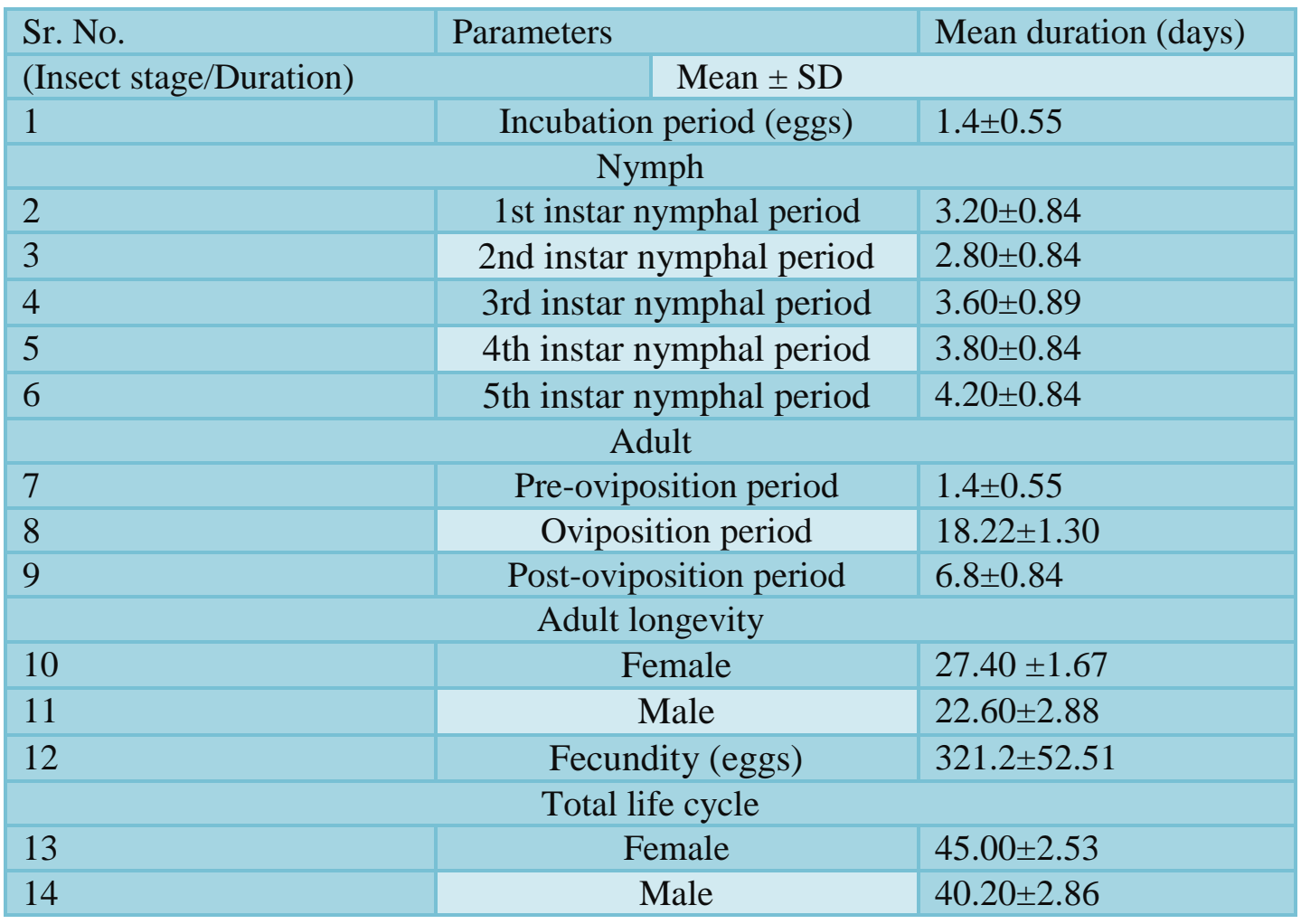
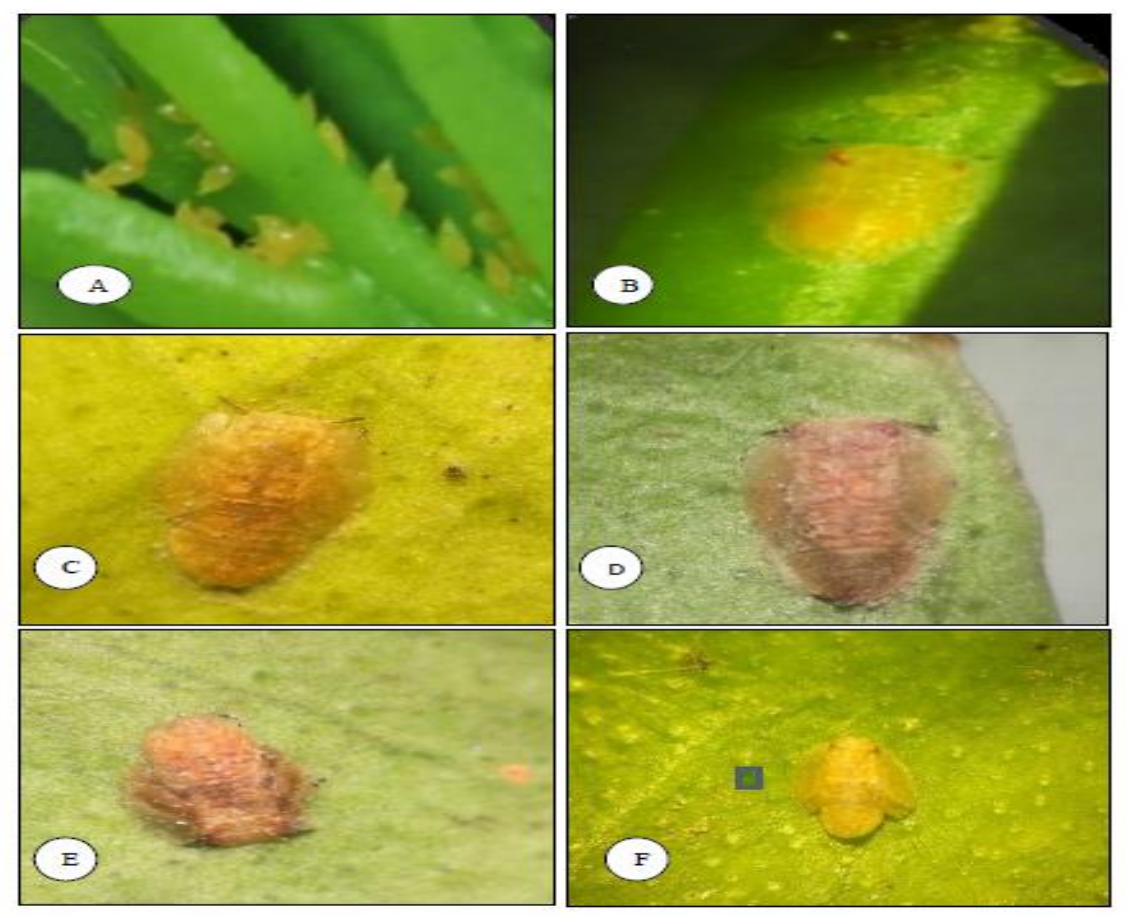

Plate-1: A: Eggs of D-citri

B: I-Instar nymph

C: II-Instar nymph

D: III-Instar nymph

F: V-Instax nymph 

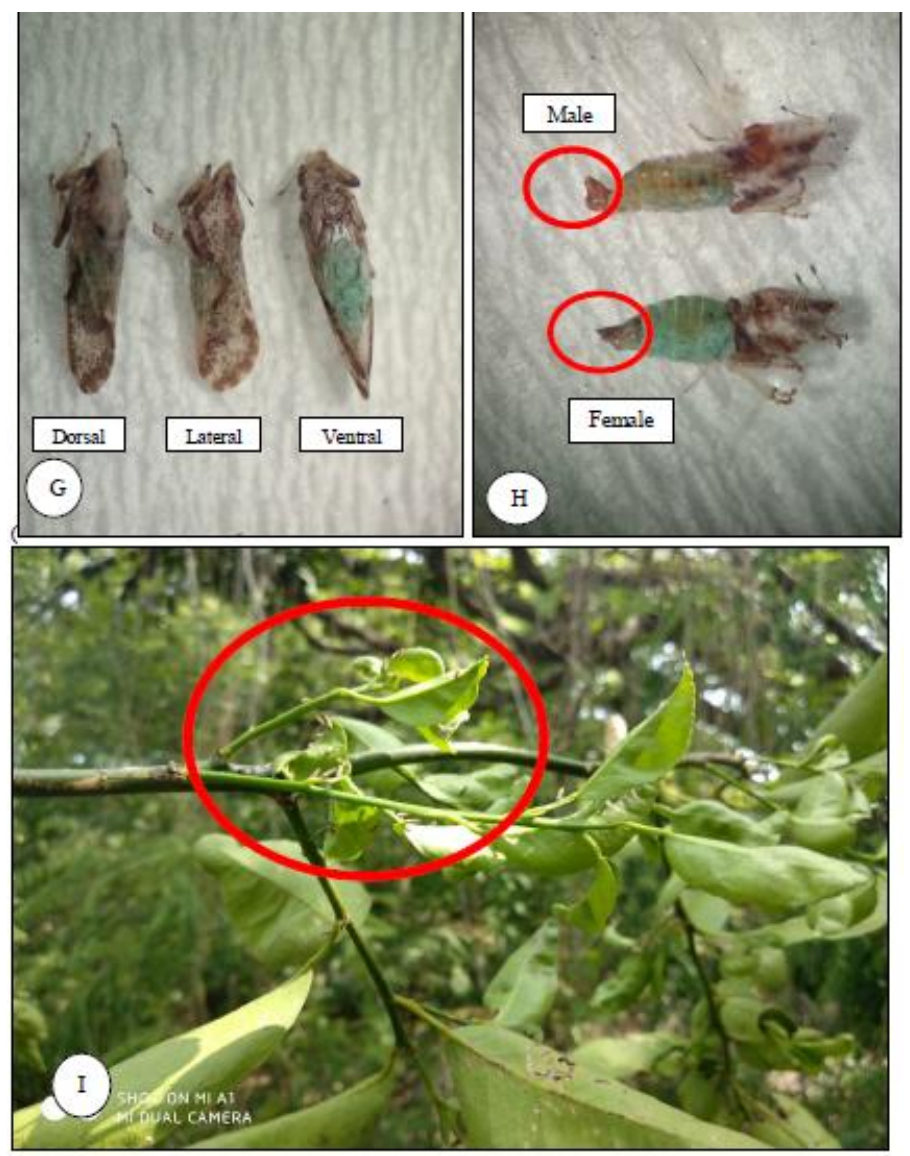

Plate-2: G: Adults of $D$. citri

H: Male and Female

I: Attack on citrus plant by $D$. citri

Plate-3: J: Rearing glass jar in BOD

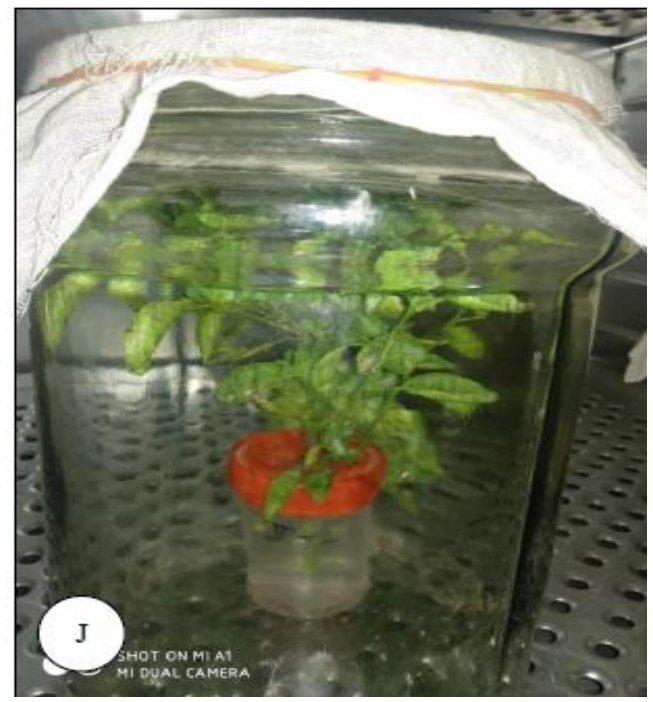



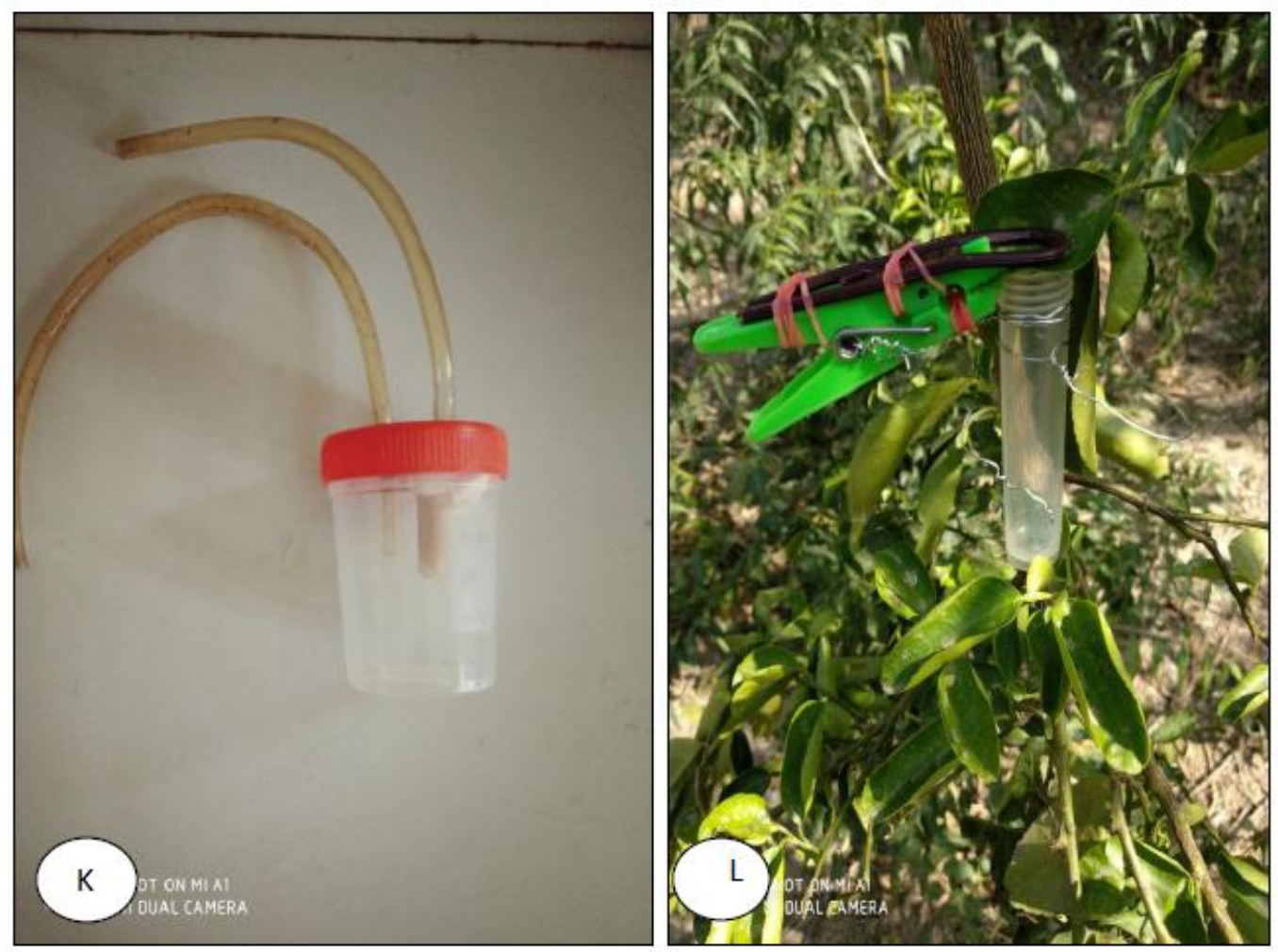

Plate-4: $\quad K \therefore$ Aspirator for collection of adults

$L$ i: Clip cage used for observation of fecundity

In conclusion, citrus psylla are prevalent throughout the year but the high population coincides with the periods of new vegetative flushes on citrus plants during spring and summer. The population is sensitive to high rainfall and moisture condition and survives throughout the year without diapause. The life cycle of Asian Citrus Psylla includes an egg stage and five nymphal instars. Eggs are oviposited in clusters on leaf folds, petioles, axillary buds, upper and lower surfaces of young leaves and tender stems. Preoviposition period lasted for $1.4 \pm 0.55$ days. The egg laying started on fourth day with an incubation period of $1.4 \pm 0.55$ days and oviposition lasted for $18.22 \pm 1.30$ days. Eggs were anchored on a stalk-like process arising from the plant tissue. They were somewhat conical, almond shaped with a broad basal end and tapering towards its distal end. Light yellow coloured eggs deposited freshly, turned bright orange later with two distinct red eye spots at maturity. The early instars were docile and moved slightly on disturbances while older nymphs and adults were highly mobile and jump frequently. They feed on tender and succulent leaves. Newly emerged nymphs were pale yellow to light pink in colour. The duration for first, second, third, fourth and fifth instar were recorded as $3.20 \pm 0.84,2.80 \pm 0.84,3.60 \pm 0.89$, $3.80 \pm 0.84,4.20 \pm 0.84$ days. Fecundity of an adult female was recorded to be $321.2 \pm 52.51$ eggs. Adult longevity was recorded 27.40 \pm 1.67 days for female and $22.60 \pm 2.88$ for male psyllid. Life cycle of male and female were completed in $40.20 \pm 2.86$ and $45.00 \pm 2.53$ days respectively. 


\section{References}

Ahmed, S., Ahmad, N. and Khan, R. R. (2004). Studies on population dynamics and chemical control of citrus psylla, Diaphorina citri. International J. Agric. Biol., 6 (6): 970-973.

Aubert, B., Grisoni, M., Villemin, M., Rossolin, G. (1996). Proceedings of 13th Conference of International Organization of Citrus Virologists (IOCV).

Aubert, B., (1987). Triozaerytreae Del Guercio and Diaphorina citri Kuwayama (Homoptera: Psylloidea), the two vectors of citrus greening disease: Biological aspects and possible control strategies. Fruits, 42(3), 149162.

Aubert, B. and Quilici, S. (1988). Monitoring adult psyllas on yellow traps in Reunion Island. Proceedings of the 10th Conference of the International Organization of Citrus Virologists, 1721 November 1986, Valencia, Spain (ed. by LW Timmer, SM Garnsey\& L Navarro), pp. 249-254. International Organization of Citrus Virologists, University of California, Riverside, CA, USA.

Bhut, G.D., Borad, P.K. and Gadhiya, V.C. (2012). Susceptibility of citrus species to psylla, Diaphorina citriKuwayama International Journal of AgriculturalScience, 1(2):215-220.

Bove, J.M. (2006). Huanglongbing: a destructive, newly emerging, century old disease of citrus. J. Plant Pathol. 88(1):7-37.

Catling, H.D. (1970). Distribution of psyllid vectors of citrus greening disease with notes on the biology and bionomics of Diaphorina citri.

Chhetry, M., Gupta, R., and Tara, J. S. (2012). Bionomics of Diaphorina citri Kuwayama (Hemiptera: Psyllidae) on
Citrus sinensis in Jammu Region of $\mathbf{J}$ and $\mathrm{K}$ State. Munis Entomology and Zoology, 7(1), 304-308.

Committee, N.P. (2010). Pharmacopoeia of People's Republic of China. Beijing: China Medicinal Science and Technology Press.

Devi, H.S. and Sharma, D.R. (2014). Impact of abiotic factors on build-up of citrus psylla, Diaphorina citri Kuwayama population in Punjab, India. Journal of Applied and Natural Science, 6(2): 371376.

Ebeling, W. (1959). Subtropical fruit pests. Subtropical Fruit Pests., (Revd. edition). Food and Agricultural Organization of the United Nations. http://faostat3.fao.org/faostatgateway/go /to/home/E

Fung, Y.C. and Chen C.N. (2006). Effects of temperature and host plant on population parameters of the citrus psyllid (Diaphorina citriKuwayama). Formosan Entomologist 26: 109-123.

Garcia-Perez, F., Ortega-Arenas, L.D., LópezArroyo, J.I., Gonzalez-Hernandez, A., Lomeli-Flores, J.R., and RomeroNapoles, J. (2013). Morphometry of Diaphorina citri (Hemiptera: Liviidae) on six Rutaceae from Veracruz, Mexico. Florida Entomologist, 529537.

Halbert, S.E. and Manjunath, K.L. (2004). Asian citrus psyllid and greening disease of citrus: a literature review and assessment of risk in Florida. Fla. Entomol. 87(3):330-353.

Hall, D.G. and Albrigo, L.G. (2007). Estimating the relative abundance of flush shoots in citrus, with implications on monitoring insects associated with flush. HortScience. 42: 364-368.

Hall, D.G., Richardson, M.L.,Ammar, E.D. and Halbert, S.E. (2013). Asian citrus psyllid, Diaphorina citri, vector of huanglongbing disease. Entomol. Exper. 
Appl. 146:207-223.

Hall, David G., Hentz, Matthew G. and Adair, Robert C. (2008). Population ecology and phenology of Diaphorina citri(Hemiptera: psyllidae) in two Florida citrus groves. Enviromental Entomology 37: 914-24.

Horticulture Statistics Division, 2017, Department of Agriculture, Cooperation and Farmers welfare, Government of India.

Husain M.A. and Nath D. (1927).The citrus psylla (Diaphorina citri, Kuw.) [Psyllidae: Homoptera]. Memoirs of the Department of Agriculture in India, Entomological Series 10: 1-27.

International Monetary Fund, (2018). International Monetary Fund Reports.

Jayanthimala, B.R., Pratheepa, M., Verghese, A., Tripathi, P.C., Ranaganath, H.R. and Sanganal, S. (2015) Role of climatic factors on citrus psylla, Diaphorina citriKuwayama (Psyllidae: Hemiptera) in Coorg mandarin, Citrus reticulate. Blanco. Current Biotica. 9 (1):45-53.

Jha, G. K., Suresh, A., Punera, B., \&Supriya, P. (2019). Growth of horticulture sector in India: Trends and prospects. Indian Journal of Agricultural Sciences, 89(2): 314-321.

Khan, K.M., \&Borle, M.N. (1989). New host records for citrus psylla, Diaphorina citriKuwayama from India. Bulletin of Entomology (New Delhi), 30(1).

McFarland C.D. and Hoy M.A. (2001) Survival of Diaphorina citri (Homoptera: Psyllidae) and its two parasitoids, Tamarixiaradiata (Hymenoptera: Eulophidae) and Diaphorencyrtus aligarhensis (Hymenoptera: Encyrtidae), under different relative humidities and temperature regimes. Florida Entomologist 84: 227-233.

NASS, United States Department of Agriculture, 2015-16, Agricultural
Marketing Service. National Agricultural Statistics Services, Florida Citrus Statistics 2015-16, 2016.

Naveen Vikram Singh and Yadav, G.S. 2018. Bio-ecology and Management of Citrus psylla, Diaphorina citri Kuwayama on Citrus - A Review. International Journal of Current Microbiology and Applied Sciences. 7 (04): 3091- 3107.

Richardson, M.L., and Hall, D.G. (2013). Resistance of Poncirus and Citrus $\times$ Poncirus germplasm to the Asian citrus psyllid. Crop Science, 53(1), 183-188.

Shivankar, V.J., Rao, C.N. and Singh, S. (2005). Studies of citrus psylla, Diaphorina citri Kuwayama: A review, Agricultual Review 21: 199-204.

Skelley, L.H. and Hoy, M.A. (2004). A synchronous rearing method for the Asian citrus psyllid and its parasitoids in quarantine. Biological Control 29: 14-23.

Sule, H. and Muhamad, R. (2014). Dynamics and distribution of Diaphorina citri (Hemiptera: Psyllidae) in a citrus orchard in Terengganu, Malaysia. Scientific Papers. Series A. Agronomy, 7: 461-465.

Tirtawidjaja, S.; Hadiwidjaja, T. and Lasheen, A.M. (1965). Citrus vein phloem degeneration virus, a possible cause of citrus chlorosis in Jawa. Proc. Amer. Soc. Hort. Sci., 86: 235-243.

Tsai, J.H., and Liu, Y.H. (2000). Biology of Diaphorina citri(Homoptera: Psyllidae) on four host plants. Journal of Economic Entomology, 93(6), 17211725.

Tsai, J.H.; Wang, J and Liu, Y. (2002). Seasonal abundance of the Asian citrus psyllid, Diaphorina citri(Homoptera :Psyllidae) in southern Florida. Florida Entomologist, 85 (3): 446-451.

United Nations Conference on Trade and Development (UNCTAD), (2004). Market Information in the Commodities 
Area: Information on citrus fruit.

United State Department of Agriculture (USDA), (2006). National Agricultural Statistics Service.

Viraktamath, C.A. and Bhumannavar, B.S. (2002). Biology, ecology and management of Diaphorina citri Kuwayama (Hemiptera: psyllidae). Pest Management of Horticultural Ecosystem 7: 1-27.5.

Wang, H, Chen, G, Lin, $\mathrm{H}$ and Gong, J. (2002). Studies on the population dynamics of citrus pests and diseases and control methods. South China Fruits, 31(4): 13-15.
Wankhade, S.M., Kadam, U.K., Patil, S.K. and Bansode, G.M. (2015). Studies on the seasonal incidence and management of citrus psylla (Diaphorina citriKuwayama) in sweet orange. Indian Journal of Agricultural Research, 49 (4): 321-326.

Wenninger, E.J., and Hall, D.G. (2008). Daily and seasonal patterns in abdominal color in Diaphorina citri(Hemiptera: Psyllidae). Annals of the Entomological Society of America, 101(3): 585-592.

Xu, C., Xia, Y., \&Ke, C. (1994). Study on the biology and control of citrus psylla. Acta Phytophylacica Sinica, 21(1): 5356.

\section{How to cite this article:}

Archi Roy, Parvez Qamar Rizvi and Neha Sinha. 2020. Biological Attributes of Diaphorina citri Kuwamaya on Citrus limetta under Controlled Conditions. Int.J.Curr.Microbiol.App.Sci. 9(03): 80-88. doi: https://doi.org/10.20546/ijcmas.2020.903.010 